Atas do XI Congresso Internacional de Educação Familiar - Família Plural, Educação Singular Universidade de Coimbra, 11 a 14 de Abril de 2007

\title{
A APRENDIZAGEM NO SEIO DA FAMÍLIA ANALFABETA
}

\author{
Bravo Nico ${ }^{1}$ \\ Luísa Carvalho ${ }^{2}$ \\ Lurdes Nico ${ }^{3}$ \\ Joana Silva ${ }^{4}$
}

\section{Introdução}

$\mathrm{O}$ analfabetismo ainda é um fenómeno presente na realidade portuguesa. Na região Alentejo, a dimensão quantitativa deste fenómeno apresenta percentagens elevadas, sendo possível identificar famílias cujos membros (nomeadamente o casal) são analfabetos.

Quase sempre associado a uma inexistência de oportunidades de aprendizagens formais e de cultura letrada, em todas as famílias ocorrem aprendizagens. As famílias compostas por indivíduos analfabetos não se constituem como uma excepção.

$\mathrm{O}$ analfabetismo tem, no entanto, vindo a assumir, na época contemporânea, novos contornos conceptuais e novas perspectivas que explicam as suas causas, respectivas consequências e novas fronteiras que deixam evidente a existência de formas alternativas de aprendizagem, de cultura e de entendimento do mundo.

Aprender, sem utilizar as próteses cognitivas que são as letras, as palavras e os cálculos elementares, através de algoritmos deterministicamente cartesianos, é, certamente, um processo complexo de realizar e de conhecer, nomeadamente quando essas aprendizagens se processam no seio de uma família analfabeta.

\section{Educação Familiar}

Covas (2006) afirma que o conceito de família encerra alguma ambiguidade devido às múltiplas formas na sua utilização, sendo que, quando referido no singular, este termo é tão abstracto que quase oculta a diversidade e complexidade que encerra.

Ainda assim, e independentemente da complexidade inerente ao conceito, Cavaco (2002) chama a atenção para o facto de o meio familiar onde os indivíduos se encontram inseridos assumir um carácter formativo, uma vez que os acontecimentos vivenciados fazem parte da rotina, tendendo a dar origem às aprendizagens mais estruturantes e significativas da vida das pessoas.

Vara (1996: 8) realça, a este respeito, que a família se constitui como «(...) o primeiro, o mais fundamental e o mais importante grupo social de toda a pessoa, bem como o seu quadro de referência, estabelecido através das relações e identificações que a criança criou durante o desenvolvimento», constituindo-se, desta forma, como a matriz da identidade. De acordo com o mesmo autor, a família apresenta-se como sendo a unidade básica da sociedade, muito embora tenha sofrido transformações decorrentes de mudanças sócio-culturais e tecnológicas, que originaram, por sua vez, distintas estruturas e composições familiares.

A família continua, ainda assim, a ser o ponto de partida e de chegada de muitas aprendizagens. Com efeito, são muitas as aprendizagens que ocorrem no seio familiar, por meio de um «intercâmbio de gerações, ou seja uma transferência de sabedorias e conhecimentos dos mais novos para os mais velhos como também dos mais velhos para os mais novos (ponte de gerações)» (Duarte et al, 2004: 191). Tal contribui, nas palavras de Orta (2003), para «o preservar da identidade - do património cultural, memória social e raízes do passado».

Evidenciando a questão da transmissão de aprendizagens de alguns membros da família aos seus descendentes, D’Espiney (2004: 81) realça que «é pelas emoções vividas e sentidas

\footnotetext{
${ }^{1}$ Departamento de Pedagogia e Educação da Universidade de Évora

${ }^{2}$ Escola Superior de Educação do Instituto Politécnico de Portalegre

${ }^{3}$ Direcção Regional de Educação do Alentejo

${ }^{4}$ Escola Comunitária de São Miguel de Machede
} 
pelas gerações que se encontram os momentos de troca se tornam mágicos: o idoso que recorda, recontando a sua memória, revive não apenas os acontecimentos que relata mas o modo como os sentiu; a criança ou o jovem que o escuta reconstitui esses acontecimentos, transferindo-os para o presente e sentindo-os no presente. Ao trazer o passado para o presente, a criança não recupera apenas o passado, reconstrói-o e projecta-o para o futuro; ao viajar pelo passado, o idoso reconcilia-se com o seu presente».

As aprendizagens que predominam, neste ambiente, são, assim, de natureza informal. «(...)Os processos educativos ocorrem (...) fora das estruturas formalizadas; não têm um conteúdo definido previamente, nem um programa pré-estabelecido (...)» (Cavaco, 2002: 38).

Tizard e Hughes (1984, cit. por Mata, 2006), reforçando a importância do lar/seio familiar como ambiente de aprendizagem, consideram que a sua eficácia reside em cinco factores:

1) A extensa variedade de actividades que são desenvolvidas em casa ou a partir dela, todas proporcionando às crianças modelos e oportunidades para aprenderem coisas sobre diversos domínios;

2) Pais e filhos partilharem uma vida em comum, facilitando, assim, a compreensão do que cada um diz, relacionando acontecimentos passados e presentes, atribuindolhes um significado mais vasto;

3) Um número reduzido de crianças por adulto, o que permite maior disponibilidade e uma atenção mais individualizada;

4) A aprendizagem ocorrer de forma contextualizada, em situações com significado para as crianças;

5) A relação próxima e intensa entre mãe e criança.

Ainda de acordo com Mata (2006), o potencial de aprendizagem do lar é grande, não sendo, contudo, igual em todas as famílias, dependendo de características específicas relativamente aos diferentes elementos envolvidos. Neira (2003) reforça esta ideia ao afirmar que não há uma família modelo, mas antes modelos de famílias.

A este propósito, importa realçar que parece ser possível identificar em alguns membros da família, nomeadamente em casais, estilos próprios e comuns de aprendizagem, ao passo que, em outros casais, tal não se apresenta como sendo tão notório e evidente. Como refere Covas (2006: 19), «as famílias constituem sub-sistemas muito particulares do sistema social total e cada uma delas estabelece uma estrutura única de relações entre os sexos e as gerações».

Neste sentido, em alguns estudos, chama-se também a atenção para o papel das mulheres nas aprendizagens ocorridas em meio familiar. Desde tempos longínquos, esteve a cargo da mulher o trabalho doméstico e todas as responsabilidades inerentes à educação dos filhos (e ainda hoje isso mesmo se verifica, apesar das mudanças sociais e económicas), «Com a excepção de algumas tarefas não rotineiras, como por exemplo as pequenas reparações, as mulheres e os homens consideram como responsabilidades domésticas inerentes às esposas, a alimentação, os cuidados da roupa, o apoio e educação dos filhos e o apoio a doentes e idosos.» (Pereira, 2005: 102)

\section{Em torno do conceito de analfabetismo}

De acordo com Lima (1994: 105), o analfabetismo é um conceito antigo, mas, simultaneamente, dinâmico e evolutivo, uma vez que, sendo «plurissignificativo e sujeito a uma constelação de valores culturais, sociais, económicos», sempre dependeu dos contextos históricos e sociais das épocas em que foi estudado, utilizado e medido.

$\mathrm{Se}$, tradicionalmente, "o conceito de alfabetização traduz o acto de ensinar e de aprender a leitura, a escrita e o cálculo", na actualidade, toda essa realidade conceptual é associada a "um novo conceito - a literacia - traduz a capacidade de usar as competências (ensinadas e aprendidas) de leitura, de escrita e de cálculo. Tal capacidade de uso, escapa, assim, a categorizações dicotómicas, como sejam analfabeto e alfabetizado" (Benavente, 1996: 4).

Canário (2000: 52) afirma, a este respeito, que "o conceito de analfabetismo tornou-se, portanto muito mais vago e fluido, pois (...) sabe-se onde começa, "no grau zero da escrita", 
mas não se sabe onde acaba". O mesmo autor realça ainda a ideia de que, actualmente, o conceito de analfabetismo designa, por conseguinte, uma grande diversidade de situações.

Em Portugal, os contornos do pensamento e da construção conceptual em torno da questão do analfabetismo e da literacia tiveram, nos últimos anos, um novo impulso e ganharam nova expressão, através dos estudos de natureza neurológica, realizados por Castro-Caldas (1998).

Decorrente da investigação que levou a cabo, Castro-Caldas (1998a; 2002; 2003) sublinha que o analfabetismo, nos seus diferentes contornos, pode ser o resultado de três causas fundamentais:

i) Ser-se portador de defeito cerebral;

ii) Ser resultado da falta de prática de leitura e de escrita por aqueles que, tendo aprendido na idade própria, não incorporaram na rotina das suas vidas estas operações;

iii) Ser reflexo de problemas sociais em regiões pouco desenvolvidas.

Segundo o mesmo autor (idem, ibidem), esta última razão é a que diz respeito aos "verdadeiros analfabetos". Tratam-se de indivíduos sem escolaridade básica devido a razões sociais, mas sem defeito cerebral.

$\mathrm{Na}$ nossa investigação, assumimos como cerne do estudo, e recorrendo às palavras de Castro-Caldas, os "verdadeiros analfabetos", tendo presente a definição proposta pelo INE (Instituto Nacional de Estatística, 2003), segundo a qual o analfabeto é um "indivíduo com 10 ou mais anos que não sabe ler nem escrever, isto é, o indivíduo incapaz de ler e compreender uma frase escrita ou de escrever uma frase completa".

\section{Analfabetismo em Portugal: $O$ caso do Alentejo}

A percentagem de analfabetos literais identificados, em Portugal, no Recenseamento Geral de População realizado pelo Instituto Nacional de Estatística, em 1991, situava-se nos $11 \%$. No Recenseamento de 2001, a taxa de analfabetismo assumia um valor de $9,1 \%$.

No caso da região Alentejo, esta mesma taxa era de $17 \%$, no Recenseamento de 2001 (em 1991, a taxa situava-se nos 21,9\%).

Uma breve e simples leitura destes números, permite-nos inferir que o analfabetismo continua a ser uma realidade muito vincada na região alentejana. Em alguns concelhos do Alentejo, esta taxa ainda se situa acima dos $25 \%$, sendo que é muito frequente a existência de taxas acima dos $20 \%$. Tal facto resulta da assinalável complexidade dos contornos territoriais, culturais e sociais em que se manifesta, das circunstâncias históricas das respectivas causas e consequências e na quantidade de indivíduos envolvidos (838 140 indivíduos em Portugal, dos quais 83985 residiam no Alentejo, em 2001).

Ainda de acordo com os dados das estatísticas referidas anteriormente, relativas a 2001, a taxa de analfabetismo era, no concelho de Évora, de 9,6\%, sendo que em S. Miguel de Machede - freguesia em que foi desenvolvido o estudo de caso que, em seguida se apresenta - a taxa de analfabetismo era de $21,1 \%$.

Como se poderá depreender dos números atrás referidos, o problema do analfabetismo constitui-se, no território português, como um fenómeno com uma longa história de persistência, sendo uma realidade ainda com uma magnitude considerável na região Alentejo.

\section{Estudo Empírico}

A presente investigação decorre dos resultados obtidos no âmbito do projecto de investigação Cartografia Educacional das freguesias de São Miguel de Machede, Nossa Senhora de Machede e Torre de Coelheiros, da responsabilidade do Departamento de Pedagogia e Educação da Universidade de Évora e financiado pela Fundação Calouste Gulbenkian, no âmbito do Programa de Apoio a Projectos de Pesquisa no Domínio Educativo, tendo sido desenvolvido no período compreendido entre os anos de 2002 e 2004. 
Nesta comunicação, efectua-se a análise a entrevistas efectuadas a dois casais não alfabetizados da freguesia de São Miguel de Machede (concelho de Évora) procurando-se os respectivos ambientes e estilos de aprendizagem, com especial destaque para as aprendizagens que ocorrem no seio da família.

Com a realização destas entrevistas, pretendia-se conhecer as últimas aprendizagens realizadas, a caracterização dos mesmos, as razões/ motivações que conduziram à aprendizagem.

O presente estudo compreende três abordagens sucessivas e complementares, que se podem traduzir, esquematicamente da seguinte forma:

Tabela 1 - Procedimento Metodológico

\begin{tabular}{|c|l|}
\hline Procedimentos Metodológicos & \multicolumn{1}{c|}{ Descrição } \\
\hline $\mathbf{1}$ & $\begin{array}{l}\text { Estudo descritivo conducente à obtenção do perfil de } \\
\text { aprendizagem de cada indivíduo e, consequentemente de } \\
\text { cada casal. }\end{array}$ \\
\hline $\mathbf{2}$ & Estudo descritivo e comparativo entre ambos os casais. \\
\hline $\mathbf{3}$ & $\begin{array}{l}\text { Estudo descritivo das aprendizagens ocorridas no seio de } \\
\text { cada família. }\end{array}$ \\
\hline
\end{tabular}

\subsection{Breve Caracterização dos Sujeitos da Amostra}

Os indivíduos entrevistados residem na freguesia de S. Miguel de Machede, freguesia do concelho de Évora, localizada a cerca de $20 \mathrm{~km}$ da sede de concelho/capital de distrito.

A amostra é constituída por dois casais: dois sujeitos do sexo feminino e dois do sexo masculino, com idades compreendidas entre os 69 e os 79 anos.

\section{2- O Estudo no Seio do Casal}

\subsection{1-Perfil Individual de Aprendizagem dos Indivíduos do Casal 1}

\section{Indivíduo $A$}

O sujeito A, do sexo feminino, com 69 anos de idade, quando questionado acerca das suas últimas aprendizagens, afirmou que aprendeu de tudo. As suas últimas aprendizagens foram muito diversificadas; aprendizagens as escolares, (ocorridas aquando da idade escolar), "na escola a última coisa que aprendi foi os problemas, ditados, essa coisa dos verbos...da letra romana..." (1.3.10) e o último trabalho que exerceu: "a última coisa que fiz foi apanhar pedra, a juntar pedra..." (1.3.10). A sua aprendizagem preferida era a ceifa "É uma coisa que gostava muito. Estava muito calor. Mas gostava mais da ceifa do que da monda" (1.3.13.)

Como causa das suas aprendizagens esteve a necessidade financeira: "Para ganhar um bocadinho de pão..." (1.4.8).

Encarando a aprendizagem como sendo constante à vida e afirmando que se aprende durante o decurso desta: "aprender até morrer..." (1.4.15), apresenta, no entanto, uma visão não muito clara, acerca da aprendizagem em determinados momentos da vida. Na realidade, por um lado, afirma que "quando se é mais velho... vai sabendo..." (1.4.16), mas também que "algumas que eu sei fazer... quando eu nunca fiz. Gosto que me ensinem. Mas fiz muitas coisas há muitos anos e que tenho ali feitas, mas parece-me que hoje já não sou capaz...” (1.10.2).

As suas aprendizagens ocorreram numa instituição formal escolar "Andei à escola" (1.1.8). Inclusivamente, refere que ainda "fiz o exame da $3^{a}$ classe" (1.1.9). Actualmente, o local propício às suas aprendizagens é a Escola Comunitária de São Miguel de Machede, uma vez que "Onde aprendo? Na SŨ̃O" (1.13.2). Contudo, quando questionada acerca das aprendizagens na generalidade, afirma que se aprende "em todo o lado. Em todo o sítio. Há certas coisas que não sabia e que fiquei a saber...” (1.5.10).

Relativamente às companhias das suas aprendizagens, refere com maior frequência as aprendizagens individuais, uma vez que "aprendia sozinha" (1.3.8). Este sujeito salienta ainda 
a importância de pessoas mais velhas na aprendizagem, pois nos trabalhos do campo havia responsáveis, "havia manajeiros, mas haver assim alguém de família que me dissesse: arrancas esta erva, que é assim ou assim, não (...) como via os outros arrancar, era como fazia também." (1.1.6)

Quanto aos recursos da aprendizagem, afirma que o dinheiro é essencial nas aprendizagens, uma vez que "Quem não tem dinheiro não aprende nada" (1.6.8).

Relativamente às estratégias de aprendizagem, refere o recurso a pessoas que já sabem: "havia manajeiros, (...) como via os outros arrancar, era como fazia também." (1.1.6).

Ao avaliar as suas aprendizagens, refere a importância da auto-avaliação: "às vezes quando vejo que não tá bem feito, desmancho... Vejo que não tá bem feito, não tá à minha vontade, desmancho" (1.9.13), e da avaliação por terceiros, através do reconhecimento social "Então pois claro. Quero apresentar aquilo que elas iam gostar... até podiam não gostar..." (1.10.12)

Tem projectos de aprendizagens futuras em diferentes dimensões "por isso é que lá ando [Escola Comunitária] para ver se ainda sou capaz de ir fazendo alguma coisa que aprendi" (1.2.1). Directamente relacionado com este projecto, refere um outro: "era desenho o que eu mais gostava de aprender. É uma coisa que não sei fazer. É o que mais me custa... todas saberem fazer, eu não fazer como elas..." (1.11.2).

A aprendizagem encontra-se, para si, relacionada com o sentimento de realização pessoal e com o sentimento de capacidade de aprender "Para isso é que lá ando [Escola Comunitária] para ver se ainda sou capaz de ir fazendo alguma coisa que aprendi" (1.2.1).

Quando solicitado a identificar aprendizagens não sucedidas, refere unicamente as aprendizagens de âmbito escolar. Recorda que "gostava, até chorava porque queria aprender e não era capaz. Não tinha cabeça e ainda chumbei dois anos... Mas hoje se fosse assim, se calhar já fazia..." (1.12.4), sendo a razão do insucesso a não obrigação de frequentar a escola "Mas aos treze éramos obrigados a sair. Não éramos obrigados a lá andar..." (1.2.3).

Ao contrário das anteriores, todas as aprendizagens reconhecidas como sucedidas, estão associadas ao trabalho de campo, chegando a afirmar que "aprendi de tudo..." (1.1.1).

A preferência deste sujeito recai nas aprendizagens com grau de dificuldade elevado, já que "Eu gostava assim de coisas mais custosas. Até nas rendas que fazia, eu não gostava de fazer pequeninas, fazia logo grandes. Gostava mais de fazer coisas grandes.” (1.12.10).

Refere, como praticamente inexistentes, as oportunidades de aprendizagem na sua freguesia de residência, pois "isto aqui... pouca gente" (1.13.1), sendo a Escola Comunitária (ambiente não formal) o único sítio onde poderão ocorrer aprendizagens.

\section{Indivíduo B}

As últimas aprendizagens recordadas por este sujeito, do sexo masculino, de 79 anos de idade, são as que realizou para o exercício da sua profissão: pastor: "fui pastor quase toda a minha vida" (1.4.2), sendo esta a sua aprendizagem preferida: "gostava de andar com as ovelhas" (1.4.5.)

Causas subjacentes às suas aprendizagens estiveram razões de ordem financeira e "Para fazer vida..." (1.4.9.).

Este sujeito, não tendo qualquer dúvida, que "enquanto viveres vais aprendendo" (1.4.14), no entanto, diz que, no seu caso específico, as suas aprendizagens apenas ocorreram na primeira fase da vida: "aprende-se o mesmo. Agora não tenho aprendido nada. O que sei é o que já sabia” (1.5.5).

Refere o campo/espaço rural como o único espaço e tempo onde ocorreram todas as suas aprendizagens: "no campo, no monte dos lavradores..." (1.5.8.).

Quanto às companhias das aprendizagens, referiu que aprendia "sempre sozinho" (1.10.5). Contudo, chama ainda a atenção para a importância de pessoas mais velhas nesse processo, destacando aquele que "chamavam-lhe o ganhão..." (1.3.4).

Curiosamente, apesar de não ter frequentado nenhuma instituição escolar, nem ter aprendido a ler e a escrever aponta os livros como o mais importante recurso da aprendizagem "Com os livros aprende-se muito..." (1.6.4.), ao que reforça dizendo: "Porque é que as pessoas andam sempre com mapas e com coisas? Sabem onde ir e não ir... agora se perguntarem a uma 
pessoa, ela diz vai por ali e ali... e às vezes erram... assim com os livros pouco se erra..." (1.6.7)

Este sujeito refere como estratégia de aprendizagem mais utilizada: "depende da ideia de cada um..." (1.9.7.), apesar de mencionar, novamente, a importância de aprender com outras pessoas, nomeadamente quem já sabe: "tem que haver alguém ... para ir ensinando" (1.9.9).

Menciona dois tipos de avaliação das aprendizagens. Por um lado, a auto-avaliação uma vez que "por ver. Vejo. Penso: isto aqui está mal feito" (1.10.7) mas também uma dimensão de hetero-avaliação, uma vez que gosta que os outros apreciem, referindo que mostra a sua horta "a quem calha.. o ano passado até andaram a tirar fotografias aqui a esta. E à outra horta foram outros..." (1.11.1).

Indica que "o que eu gostava ainda, já não há... que era pegar numa junta de bois... numa carreta" (1.11.3), ou seja o que gostaria de fazer - o seu projecto de aprendizagem - seria tornar a realizar as aprendizagens que já tinha desenvolvido aquando da sua actividade no trabalho do campo, não apresentando qualquer vontade ou motivação para realizar aprendizagens fora da sua esfera profissional.

Apresentou uma atitude positiva face à aprendizagem associada ao prazer de aprender "Gostava muito" (1.11.14) e ao um sentimento de felicidade "Sentia. Andava todo o dia a cantar e a sorrir..." (1.11.13).

Refere "tirar cortiça nunca aprendi" (1.3.1) como a sua única aprendizagem não sucedida. Quando questionado (directamente) acerca de não ter qualquer aprendizagem escolar, o sujeito refere que "Gostava mais de andar no campo do que estar preso na escola" (1.4.13).

Nas aprendizagens consideradas como sucedidas por este sujeito, mais uma vez são identificadas as aprendizagens do trabalho do campo, pois afirma "foi de guardar ovelhas" (1.12.9), mas também refere que "sei fazer uma cozedura" (1.8.11), mas tal foi proporcionado no decorrer da sua actividade profissional "com os outros velhotes ... ia ajudar. Levava-me para lá, achavam que eu tinha mais paciência para fazer aquilo, para tratar o forno..." (1.8.12). Há que atender que este sujeito "andou quase quarenta anos a guardar ovelhas..." (1.4.3.).

Prefere aprendizagens "mais ou menos" (1.12.11), isto é aprendizagens com grau de dificuldade médio e afirma, que na sua freguesia, apenas no ambiente formal: "Na escola" (1.13.4) existem oportunidades de aprendizagem.

\subsubsection{2- Perfil Comparativo do Casal 1}

\section{(Indivíduos A e B)}

Quadro 2 - Perfil Comparativo Casal 1

\begin{tabular}{|c|c|c|}
\hline Categoria & Indivíduo A & Indivíduo $B$ \\
\hline 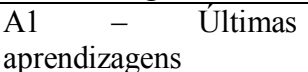 & $\begin{array}{l}\text { Juntar Pedra } \\
\text { Aprendizagens Escolares }\end{array}$ & $\begin{array}{l}\text { Pastor } \\
\text { Queijos }\end{array}$ \\
\hline $\begin{array}{l}\text { A2 - Aprendizagens } \\
\text { preferidas }\end{array}$ & Ceifa & Ovelhas \\
\hline \multicolumn{3}{|c|}{$\begin{array}{l}\text { Ambos os indivíduos gostavam de aprendizagens relacionadas com o trabalho de campo, que foi a sua } \\
\text { cipal actividade profissional. }\end{array}$} \\
\hline $\begin{array}{l}\text { B - As razões das } \\
\text { aprendizagens }\end{array}$ & \multicolumn{2}{|c|}{ Financeira } \\
\hline \multicolumn{3}{|c|}{$\begin{array}{l}\text { Tanto o indivíduo A como o indivíduo B referenciaram a necessidade financeira como causa das suas } \\
\text { aprendizagens. }\end{array}$} \\
\hline $\begin{array}{l}\mathrm{C}-\mathrm{A} \text { frequência das } \\
\text { aprendizagens }\end{array}$ & $\begin{array}{l}\text { Sempre } \\
\text { Dependente / Influência da Idade }\end{array}$ & Sempre \\
\hline \multicolumn{3}{|c|}{ Ambos os indivíduos deste casal mencionam a que a aprendizagem é feita durante toda a vida. } \\
\hline $\begin{array}{l}\text { D- Os espaços } \begin{array}{r}\text { e } \\
\text { tempos } \\
\text { aprendizagens }\end{array} \\
\text { das }\end{array}$ & $\begin{array}{l}\text { Formal } \\
\text { Não Formal } \\
\text { Informal }\end{array}$ & Informal \\
\hline \multicolumn{3}{|c|}{$\begin{array}{l}\text { Nesta dimensão, as opiniões divergem: um dos elementos do casal afirma que todos os ambientes } \\
\text { (formais, não formais e informais) são espaços e tempos de aprendizagem, enquanto que o outro apenas } \\
\text { referencia os ambientes informais como promotores de aprendizagem. Tal pode ficar a dever-se ao facto de o } \\
\text { indivíduo A ter frequentado uma instituição escolar (a escola) e ter continuado a realizar aprendizagens nesse } \\
\text { âmbito, ao frequentar o Curso de Educação de Adultos, na instituição de educação não formal local: SUÃO } \\
\text { (Escola Comunitária de São Miguel de Machede). O indivíduo B nunca frequentou a escola, nem realizou }\end{array}$} \\
\hline
\end{tabular}


outras aprendizagens senão aquelas que estavam relacionadas com o seu modo de subsistência que era o trabalho do campo (ambiente informal de aprendizagem).

E - As companhias das

aprendizagens

Individualmente

Tanto o indivíduo A como o indivíduo B referem com maior frequência as aprendizagens individuais, referindo ainda a importância de pessoas mais velhas nas aprendizagens, pois a actividade profissional de ambos esteve relacionado com a actividade agrícola e nos trabalhos do campo havia os responsáveis pelas aprendizagens das tarefas.

\begin{tabular}{|l|l|l}
$\begin{array}{l}\text { F - Os recursos das } \\
\text { aprendizagens }\end{array}$ & $\begin{array}{l}\text { Pessoas } \\
\text { Meios de Comunicação } \\
\text { Livros } \\
\text { Dinheiro }\end{array}$ & Livros \\
\end{tabular}

Os elementos do casal não concordam totalmente com os recursos mais utilizados nas aprendizagens, apesar de concordarem que as pessoas são bons recursos de aprendizagem. $O$ indivíduo $A$ refere vários outros recursos, com especial relevância para o dinheiro, enquanto que o indivíduo B afirma como essenciais os manuais / livros.

\begin{tabular}{l|c}
$\mathrm{G}-$ As estratégias das & Pensa e Faz \\
aprendizagens & Aprende com quem sabe
\end{tabular}

Ambos os elementos do casal referem como estratégias por eles utilizadas nas aprendizagens, o pensamento e a acção crítica. Outro ponto de concordância dos elementos do casal recai na valorização da aprendizagem com o auxílio dos mais experientes, também por terem reconhecido que as pessoas mais velhas são suas companhias nas aprendizagens que realizam.
H- A avaliação das
Auto-Avaliação

aprendizagens

Hetero-Avaliação

Nesta categoria, ambos os elementos do casal referem que só depois de fazerem uma auto-avaliação das suas aprendizagens e esta for positiva, se colocam à disposição da avaliação das outras pessoas.

\begin{tabular}{l|l|l} 
I - Os projectos de & Diferentes Aprendizagens Escolares & Serviços do Campo
\end{tabular}

aprendizagem $\quad$ Desenho

Nesta categoria, os elementos do casal diferem. Enquanto que um dos elementos ambiciona e faz projectos de âmbito escolar, o outro prefere projectos relacionados com o trabalho do campo.

\begin{tabular}{|l|l|l|}
$\mathrm{J}-$ As atitudes face às & Sentir-se Capaz de Aprender & Gostar de Aprender
\end{tabular} aprendizagens

$\mathrm{O}$ indivíduo $\mathrm{A}$ apresenta uma atitude face à aprendizagem relacionada com a realização pessoal e a capacidade de aprender, enquanto que o indivíduo $B$, por seu turno, apresenta uma atitude relacionada com o prazer de aprender. De realçar que este sentimento de felicidade demonstrado pelo indivíduo $B$ advém apenas das aprendizagens relacionadas com as actividades rurais.

\begin{tabular}{l|l|l}
$\begin{array}{l}\mathrm{K} \text { - As aprendizagens } \\
\text { não sucedidas }\end{array}$ & $\begin{array}{l}\text { Desenho } \\
\text { Matemática } \\
\text { Andar à Escola }\end{array}$ & Cortiça \\
\hline
\end{tabular}

Neste casal, um dos indivíduos (A) aponta como aprendizagens não sucedidas as de âmbito escolar, enquanto que o outro (indivíduo B), referencia, novamente, uma aprendizagem relacionada com o trabalho em contexto rural.

\begin{tabular}{l|l|l|}
$\begin{array}{l}\text { L- As aprendizagens } \\
\text { sucedidas }\end{array}$ & $\begin{array}{l}\text { Serviços do Campo } \\
\text { Diferentes aprendizagens escolares }\end{array}$ & Serviços do Campo \\
\hline
\end{tabular}

Ambos identificam, maioritariamente, aprendizagens sucedidas as relacionadas com o trabalho do campo.

\begin{tabular}{lr|l|l}
\hline $\begin{array}{l}\text { M Grau de } \\
\text { Dificuldade } \\
\text { aprendizagens }\end{array}$ & Difícil & Médio \\
\hline
\end{tabular}

Os sujeitos não concordam acerca do grau de dificuldade que procuram nas suas aprendizagens. Um (indivíduo A) prefere aprendizagens difíceis "mais custosas" enquanto que o outro (indivíduo B) prefere aprendizagens de grau de dificuldade médio.

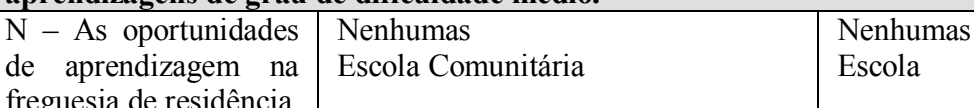

freguesia de residência

As respostas deste casal divergem, pois enquanto um dos indivíduos (A) frequenta uma Escola Comunitária e a referencia como espaço propício à aprendizagem, o outro indivíduo (B), apesar de não ter frequentado nenhuma instituição educativa formal, ou ter apresentado durante a entrevista qualquer vontade ou motivação para o fazer, valoriza e reconhece a importância das aprendizagens escolares, ao referir o ambiente formal (escola básica da freguesia).

Ambos dizem que as oportunidades de aprendizagem na sua freguesia são diminutas.

\subsection{2-Perfil Individual de Aprendizagem dos Indivíduos do Casal 2 Indivíduo $C$}


Este indivíduo, de sexo feminino, de 69 anos de idade, quando questionado acerca da sua última aprendizagem afirma: "A última? Foi escrever sem estar a ler do livro" (2.1.1). E de todas as suas aprendizagens, a sua preferida é "a coisa que sempre adorei, sempre, sempre, sempre foi o corte e costura. Adorava” (2.2.10).

As razões que o levaram a aprender foram, principalmente, de duas ordens: por um lado pelo prazer - gosto que as aprendizagens lhe proporcionavam: "Gosto de aprender tudo" (2.3.14), mas também pela vaidade e primor, já que "... toda a vida foi assim, muito vaidosa do quer que for que faça, mesmo que ele esteja feio, mas eu gosto e sou primorosa com isso..." (2.3.17). Por outro lado, para realização pessoal "Para me sentir capaz" (2.3.19).

Assegura que "aprende-se sempre... aprende-se sempre." (2.6.18), ao que reforça mencionando o carácter diário das aprendizagens: "Todos os dias" (2.4.24). Contudo, refere igualmente determinados momentos da vida como sendo mais propícios à aprendizagem, o que se constata quando afirma que "mas quando se é mais nova, aprende-se melhor" (2.6.20).

Declara que "ai não, o aprender não tem sítio" (2.7.8.), salientando "por exemplo em casa" (2.5.4.) - um ambiente informal de aprendizagem - mas também refere, como espaço de aprendizagem, o formal pois "não, não tirei curso lá na Singer em Elvas" (2.1.15). Menciona, ainda, com bastante expressividade, um ambiente não formal de aprendizagem "fui à SUÃO" (2.6.16). Actualmente, frequenta, nessa Escola Comunitária, um Curso de Educação de Adultos, onde realiza a maioria das suas aprendizagens individualmente e "com a minha ideia" (2.7.13).

Para realizar as suas aprendizagens, recorre a um leque diversificado de recursos. Por um lado, "com toda a gente se aprende" (2.9.12), por outro lado, nos meios de comunicação, nomeadamente na televisão: "a gente dá uma coisinha na televisão mesmo que a gente não ligue, mas há sempre uma coisinha que a gente gosta de ouvir" (2.9.11) mas também os manuais/ livros "Não, não era mesmo na casa das máquinas. Tenho lá o livro" (2.1.4).

Este indivíduo diz, quanto às estratégias de aprendizagem e no seguimento do que anteriormente já tinha afirmado, que aprende individualmente. Umas vezes pensa e faz: " $n a$ máquina pensava e depois ia fazendo" (2.2.15), mas também através da memorização " $E$ eu sem saber ler nem nada, decorei aquilo tudo e fui a número um" (2.1.16). Também refere como estratégia de aprendizagem, a reprodução do modelo "vi, tentei e fiz" (2.4.27) e a importância das aprendizagens anteriores "sim... às vezes, há coisas que nascem umas das outras... e há uma coisa qualquer e têm a capacidade de crescer..." (2.9.22).

Salienta a importância da auto-avaliação: "a gente vê logo que já faz bem” (2.10.1), mas também "gosto de mostrar aos outros, sou vaidosa" (2.10.5).

Um projecto de aprendizagem futura é, nas suas palavras: "Isto do ler... não desisto" (2.10.20), mas afirma que "Gosto sempre de aprender. Aprender mais em tudo" (2.10.15).

Como aprendizagem não sucedida salienta "só as contas de dividir é que tenho tido sempre dificuldade nelas" (2.6.10), "mas tenho pena de não ter acabado, pois sei... faço calças, faço tudo, mas não tenho carta" (2.2.14).

As aprendizagens "recheadas" de sucesso para este sujeito são as desenvolvidas no âmbito da sua aprendizagem preferida: o corte e costura, sendo que "só de ideia, ainda hoje trabalho, faço tudo, quase tudo, fiz as roupas da minha filha até ela se casar...fiz tudo, malhas... tudo" (2.2.13).

Quanto ao grau de dificuldade das aprendizagens, afirma que "eu gosto difícil"

Para este indivíduo as únicas oportunidades de aprendizagem existentes em São Miguel de Machede "só na SUÃO" (2.10.28) e mais "nada” (2.10.27).

\section{Indivíduo D}

A última aprendizagem deste indivíduo (do sexo masculino, de 73 anos de idade) tinha sido um trabalho realizado no âmbito do curso de Educação de Adultos, que frequenta na sua freguesia de residência: "A última coisa que escrevi, a última coisa que pensei... foi agora há bocadinho...estar a ler o ditado que a ... me fez a semana passada” (2.1.2). 
O sujeito aprendeu principalmente por necessidade financeira, já que "precisava de trabalhar, para ganhar, para me governar" (2.4.18) e pelo prazer e orgulho, uma vez que "era orgulhoso em aprender tudo" (2.4.14).

Para si, as aprendizagens ocorrem permanentemente, "a toda a hora" (2.5.1) e "o aprender não tem sítio" (2.7.9.), elegendo, deste modo, o ambiente informal como espaço e tempo de aprendizagem privilegiado.

As suas aprendizagens são realizadas maioritariamente com elementos da sua família, mais especificamente "eu mais a minha mulher" (2.9.17), mas também "com o meu pai aprendi muita coisa" (2.8.8) e refere, ainda, o papel importante do sogro na sua aprendizagem "por aquilo que o meu sogro me ensinou" (2.8.12). Para este sujeito é necessário reservar um espaço para as aprendizagens realizadas em grupo e com outras pessoas, nomeadamente pessoas mais velhas e que sabiam "havia aqueles homens, os encarregados, os que sabia mais do que nós" (2.8.2) e também “aquele amigo" (2.9.18).

Para aprender recorre unicamente às pessoas: "aquela pessoa sabe, e eu tenho que ouvir... e eu oiço e aprendo" (2.9.19). Na verdade, o aprender com quem é mais experiente, é a estratégia fundamental para a sua aprendizagem, uma vez que "é muito importante uma pessoa saber para ensinar o outro a pensar" (2.9.2.), mas também a repetição/reprodução do modelo "gosto de aprender com outra pessoa e depois fazer igual" (2.8.15).

Aquando da avaliação das aprendizagens, afirma que "o que se faz é para ficar bem feito, senão é para melhorar e depois mostrar... para ficar melhor, os outros dizerem: está como a lei" (2.10.11).

Face às aprendizagens, apresenta uma atitude positiva relacionada com o sentimento de capacidade, uma vez, como refere: "fui capaz" (2.10.25).

Como aprendizagens não sucedidas foram referidas as aprendizagens da leitura e da escrita, uma vez que "a minha dificuldade é ter aqui um papel e depois perguntar a letra e eu esqueço-me" (2.10.19). Também refere a tiragem da cortiça, pois fez de tudo "menos tirar cortiça" (2.4.3.), mas tal ficou a dever-se ao facto de "não calhou ir para lá... não ia ocupar aquele lugar" (2.4.4.).

Todas as aprendizagens sucedidas estão relacionadas com os trabalhos do meio rural: "eu aprendi todos os trabalhos, todos, todos" (2.4.2).

Prefere aprendizagens com um grau de dificuldade elevado, chegando a afirmar que "quanto mais dificeis forem as coisas, mais gosto há em aprender" (2.10.13),

As oportunidades de aprendizagem na sua freguesia de residência, no seu entender, localizam-se num único lugar: "É tudo na SUÃO” (2.10.31) e que "não em São Miguel não há lugar" (2.10.30).

\subsubsection{2- Perfil Comparativo do Casal 2 (Indivíduos C e D)}

Quadro 3 - Perfil Comparativo Casal 2

\begin{tabular}{|c|c|c|c|}
\hline Categoria & & & Indivíduo $D$ \\
\hline $\begin{array}{l}\text { A1 } \quad-\quad \text { Últimas } \\
\text { aprendizagens }\end{array}$ & \multicolumn{3}{|c|}{ Cópia / Ditado } \\
\hline $\begin{array}{l}\text { A2 - Aprendizagens } \\
\text { preferidas }\end{array}$ & Corte e Costura & Ceifa & \\
\hline \multicolumn{4}{|c|}{$\begin{array}{l}\text { Ambos os elementos deste casal afirmam que as suas últimas aprendizagens realizaram-se no Curso de } \\
\text { Educação de Adultos, que ambos frequentam na Escola Comunitária de São Miguel de Machede (SUÃO). } \\
\text { Contudo, as suas preferências recaem, num indivíduo (C) para um gosto/hobbie enquanto que para o outro } \\
\text { (indivíduo D) para uma aprendizagem que realizou no âmbito profissional. }\end{array}$} \\
\hline $\begin{array}{l}\mathrm{B}-\mathrm{As} \text { razões das } \\
\text { aprendizagens }\end{array}$ & $\begin{array}{l}\text { Gosto } \\
\text { Vaidosa / primorosa }\end{array}$ & $\begin{array}{l}\text { Necessi } \\
\text { Orgulh } \\
\text { Desafio } \\
\text { Vontad }\end{array}$ & \\
\hline \multicolumn{4}{|c|}{$\begin{array}{l}\text { Ambos os indivíduos deste casal, referem o prazer como principal motor de aprendizagem, mas um assume } \\
\text { mais o gosto que sente ao aprender tudo, enquanto o outro refere o orgulho. }\end{array}$} \\
\hline $\mathrm{C}-\mathrm{A}$ frequência das & Sempre & Sempre & \\
\hline
\end{tabular}




\begin{tabular}{|c|c|c|}
\hline aprendizagens & $\begin{array}{l}\text { Diariamente } \\
\text { Dependente / Influência da Idade }\end{array}$ & \\
\hline \multicolumn{3}{|c|}{$\begin{array}{l}\text { Ambos os membros do casal têm opiniões semelhantes, no que diz respeito à frequência das aprendizagens, } \\
\text { pois ambos referem o carácter permanente da mesma. }\end{array}$} \\
\hline $\begin{array}{l}\begin{array}{l}\text { D- Os espaços } \\
\text { tempos } \\
\text { aprendizagens }\end{array} \\
\text { das }\end{array}$ & $\begin{array}{l}\text { Formal } \\
\text { Não Formal } \\
\text { Informal }\end{array}$ & $\begin{array}{l}\text { Não Formal } \\
\text { Informal }\end{array}$ \\
\hline \multicolumn{3}{|c|}{$\begin{array}{l}\text { Este casal concorda que se aprende em todo o lado, o que poderá estar relacionado com o carácter } \\
\text { permanente das aprendizagens, anteriormente reconhecido. }\end{array}$} \\
\hline $\begin{array}{l}\text { E - As companhias das } \\
\text { aprendizagens }\end{array}$ & $\begin{array}{l}\text { Individualmente } \\
\text { Família - Entre o Casal } \\
\text { Pessoas }\end{array}$ & $\begin{array}{l}\text { Individualmente } \\
\text { Família - Entre o Casal; Pais e Filhos; Sogro } \\
\text { Pessoas } \\
\text { Pessoas mais Velhas que Sabiam } \\
\text { Amigo }\end{array}$ \\
\hline \multicolumn{3}{|c|}{$\begin{array}{l}\text { Relativamente às companhias das aprendizagens, isto é, os parceiros associados às aprendizagens realizadas, o } \\
\text { indivíduo C salienta o carácter individual das suas aprendizagens, enquanto que o indivíduo D salienta a família } \\
\text { (destacando o papel da mulher, do pai e do sogro). }\end{array}$} \\
\hline $\begin{array}{l}\mathrm{F}-\text { Os recursos das } \\
\text { aprendizagens }\end{array}$ & $\begin{array}{l}\text { Pessoas } \\
\text { Meios de Comunicação - Televisão } \\
\text { Livros }\end{array}$ & Pessoas \\
\hline \multicolumn{3}{|c|}{$\begin{array}{l}\mathrm{O} \text { indivíduo } \mathrm{C} \text { recorre a diversas fontes/ recursos para as suas aprendizagens enquanto que o } \mathrm{s} \text { indivíduo } \mathrm{D} \\
\text { refere que apenas recorre às pessoas. }\end{array}$} \\
\hline $\begin{array}{l}\mathrm{G}-\text { As estratégias das } \\
\text { aprendizagens }\end{array}$ & $\begin{array}{l}\text { Pensa e Faz } \\
\text { Memorização } \\
\text { Aprende com quem sabe } \\
\text { Importância das aprendizagens anteriores }\end{array}$ & $\begin{array}{l}\text { Pensa e Faz } \\
\text { Tentativa e Erro } \\
\text { Aprende com quem sabe } \\
\text { Importância das aprendizagens anteriores }\end{array}$ \\
\hline \multicolumn{3}{|c|}{$\begin{array}{l}\text { As estratégias de aprendizagens do casal, vão de encontro às suas preferências relativamente aos recursos } \\
\text { de aprendizagem, isto é, se o indivíduo } C \text { refere anteriormente que aprende melhor sozinho, então, a sua } \\
\text { estratégia de aprendizagem predilecta é o pensar e fazer (até quando este indivíduo refere a reprodução de um } \\
\text { modelo, quando menciona a aprendizagem com pessoas, é sempre com base num modelo de que possa partir, } \\
\text { encarregando-se da restante aprendizagem). O mesmo acontece com o indivíduo } \mathrm{D} \text {, pois ao referir que aprende } \\
\text { mais recorrendo às pessoas, a estratégia que elege, como fundamental, é o recurso a outras pessoas mais } \\
\text { experientes. }\end{array}$} \\
\hline $\begin{array}{l}\text { H- A avaliação das } \\
\text { aprendizagens }\end{array}$ & & $\begin{array}{l}\text { Avaliação } \\
\text { Avaliação }\end{array}$ \\
\hline \multicolumn{3}{|c|}{$\begin{array}{l}\text { Os indivíduos deste casal diferem um pouco na avaliação das suas aprendizagens, o indivíduo C avalia } \\
\text { primeiro e só depois mostra aos outros. O indivíduo D privilegia a hetero-avaliação, sob a forma de } \\
\text { reconhecimento e reforço social das suas aprendizagens. }\end{array}$} \\
\hline $\begin{array}{l}\text { I - Os projectos de } \\
\text { aprendizagem }\end{array}$ & $\begin{array}{l}\text { Diferentes Aprendizagens (tudo) } \\
\text { Ler }\end{array}$ & Ler \\
\hline \multicolumn{3}{|c|}{$\begin{array}{l}\text { Ambos os elementos do casal têm projectos de aprendizagens futuras, mas enquanto o indivíduo } \mathrm{C} \text { refere as } \\
\text { aprendizagens em geral, o indivíduo } \mathrm{D} \text { especifica a leitura, como a mais importante. }\end{array}$} \\
\hline $\begin{array}{l}\mathrm{J}-\text { As atitudes face às } \\
\text { aprendizagens }\end{array}$ & \multicolumn{2}{|c|}{ Sentir-se Capaz de Aprender } \\
\hline \multicolumn{3}{|c|}{ Os elementos deste casal querem aprender, por uma questão de realização pessoal e de capacidade. } \\
\hline $\begin{array}{l}\mathrm{K}-\text { As aprendizagens } \\
\text { não sucedidas }\end{array}$ & $\begin{array}{l}\text { Matemática } \\
\text { Ler }\end{array}$ & $\begin{array}{l}\text { Ler } \\
\text { Andar à Escola } \\
\text { Cortiça }\end{array}$ \\
\hline \multicolumn{3}{|c|}{$\begin{array}{l}\text { Enquanto que para o indivíduo C as aprendizagens não sucedidas são mínimas, a listagem do indivíduo D é } \\
\text { mais extensa (mas, na sua esmagadora maioria, são aprendizagens não sucedidas no mesmo âmbito: leitura e } \\
\text { escrita). }\end{array}$} \\
\hline $\begin{array}{l}\text { L- As aprendizagens } \\
\text { sucedidas }\end{array}$ & \begin{tabular}{|l|} 
Corte e Costura \\
Outras Aprendizagens (tudo)
\end{tabular} & $\begin{array}{l}\text { Serviços do Campo } \\
\text { Matemática } \\
\text { Diferentes Aprendizagens Escolares }\end{array}$ \\
\hline \multicolumn{3}{|c|}{$\begin{array}{l}\text { Para este casal, as aprendizagens sucedidas estão relacionadas com as suas aprendizagens preferidas, corte e } \\
\text { costura e trabalhos em contexto rural, respectivamente. }\end{array}$} \\
\hline $\begin{array}{lr}\text { M } \quad \text { Grau } & \text { de } \\
\text { Dificuldade } & \text { das } \\
\text { aprendizagens }\end{array}$ & \multicolumn{2}{|c|}{ Dificil } \\
\hline \multicolumn{3}{|c|}{ ndivíduo D preferem aprendizagens de grau de dificuldade elevado. } \\
\hline $\begin{array}{l}\mathrm{N}-\text { As oportunidades } \\
\text { de aprendizagem na } \\
\text { freguesia de residência }\end{array}$ & & $\begin{array}{l}\text { inhumas } \\
\text { SUÃO }\end{array}$ \\
\hline
\end{tabular}




\section{3 - O Estudo comparativo entre os Dois Casais}

\section{Últimas aprendizagens (O quê)}

A partir do conteúdo das entrevistas realizadas foi possível identificar algumas das últimas aprendizagens realizadas por estes indivíduos, assim como as suas preferidas.

\begin{tabular}{|l|l|l|l|}
\hline \multicolumn{1}{|c|}{ Quadro 4 - Últimas aprendizagens } \\
\hline $\begin{array}{l}\text { A1 - Últimas } \\
\text { aprendizagens de } \\
\text { que se recordava }\end{array}$ & Conteúdos dos Indicadores & $\begin{array}{c}\text { Unid. } \\
\text { Reg. }\end{array}$ & $\begin{array}{c}\text { Unid. } \\
\text { Enum. }\end{array}$ \\
\hline & Escola & 6 & 1 \\
\hline $\begin{array}{l}\text { A1 Total }- \\
\text { Aprendizagens } \\
\text { Preferidas }\end{array}$ & Tudo & 1 & 2 \\
& Tricotar & 1 & 1 \\
\hline & Escola Comunitária (SUÃO) & 2 & 2 \\
\hline A2 Total & Pastoreio & 5 & 2 \\
\hline
\end{tabular}

Os indivíduos identificaram um leque diversificado nas suas últimas aprendizagens. A aprendizagem mais referenciada foi a relacionada com a aprendizagem da leitura e da escrita, como se verifica na citação de um dos indivíduos: "a p p..a.......e...l... a.. foi a última coisa" (2.1.5) 2UE. Esta aprendizagem de cópia / ditado foi a única aprendizagem referenciada por elementos dos dois casais (5UR).

As restantes aprendizagens foram reconhecidas apenas por um dos indivíduos. Exemplos disso mesmo são os serviços/trabalhos relacionados com o trabalho de campo: " $a$ última coisa que fiz foi andar no trabalho de campo" (1.1.2) 6UR/1E.

A aprendizagem preferida mais referenciada pelos indivíduos foi a ceifa: "É uma coisa que gostava muito. Estava muito calor. Mas gostava mais da ceifa do que da monda" (1.3.13) 5UR/2UE. Há que salientar o facto desta aprendizagem ser a eleita pelo elemento feminino (indivíduo A) do casal 1 e o elemento masculino (indivíduo D) do casal 2.

De notar que um sujeito refere que todas as aprendizagens que realizou - "Tudo" (1.1.1) (3UR) - foram do seu agrado.

As demais aprendizagens (pastoreio, tricotar, escola) foram apontadas apenas por um indivíduo.

\section{$\underline{\text { Razões das Aprendizagens (Porquê) }}$}

Quando questionados acerca das razões que levam à realização de novas aprendizagens, os indivíduos manifestaram-se da forma explicitada no Quadro 5.

Quadro 5 - Razões das aprendizagens (porquê)

\begin{tabular}{|c|c|c|c|}
\hline Sub-categorias & Conteúdos dos Indicadores & $\begin{array}{c}\text { Unid. } \\
\text { Reg. }\end{array}$ & $\begin{array}{c}\text { Unid. } \\
\text { Enum. }\end{array}$ \\
\hline
\end{tabular}




\begin{tabular}{|l|l|l|l|}
\hline $\begin{array}{l}\text { B1 - } \\
\text { Necessidade }\end{array}$ & Financeira & 10 & 2 \\
\hline B1 Total & & 10 & 1 \\
\hline $\begin{array}{l}\text { B2 - } \\
\text { Prazer }\end{array}$ & Vaidosa /Primorosa & 8 & 1 \\
\hline B2 Total & Orgulho & 2 & 1 \\
\hline $\begin{array}{l}\text { B3 Sentimento de } \\
\text { Realização }\end{array}$ & Desto & 2 & 1 \\
\hline B3 Total & & 12 & 1 \\
\hline $\begin{array}{l}\text { B4 - } \\
\text { Iniciativa Própria }\end{array}$ & Vontade Própria & 2 & 1 \\
\hline B4 Total & & 2 & 1 \\
\hline
\end{tabular}

Como se pode observar, foram quatro as razões apontadas como indutoras de aprendizagens: necessidade a nível financeiro (10UR), prazer (12UR), sentimento de realização (2UR) e, ainda, iniciativa própria (1UR)

A necessidade a nível financeiro foi a justificação mais referenciada pelos indivíduos, "Porque é que aprendemos...? Para ganhar..." (1.4.7) 10UR/2UE e a única justificação apontada para as aprendizagens realizadas por um dos casais.

Uma outra razão considerada relevante para que as aprendizagens ocorram é o pelo prazer sob a forma de "tudo, sou muito vaidosa" (2.3.16).

\section{Frequência das Aprendizagens (Quando)}

Quando abordados com a questão da frequência das aprendizagens, os indivíduos não adoptaram uma posição consensual, como se verifica no quadro seguinte:

\begin{tabular}{|l|l|l|l|}
\multicolumn{4}{|c|}{ Quadro 6 - Frequência das aprendizagens (quando) } \\
\hline \multicolumn{1}{|c|}{ Sub-categorias } & Conteúdos dos Indicadores & \multicolumn{1}{c|}{$\begin{array}{c}\text { Unid. } \\
\text { Reg. }\end{array}$} & $\begin{array}{c}\text { Unid. } \\
\text { Enum. }\end{array}$ \\
\hline $\begin{array}{l}\text { C1 - Ao Longo da } \\
\text { Vida }\end{array}$ & Sempre & 9 & 2 \\
\hline Todos os dias & 2 & 1 \\
\hline $\begin{array}{l}\text { C2 }- \\
\text { Em determinados } \\
\begin{array}{l}\text { Momentos da } \\
\text { Vida }\end{array}\end{array}$ & $\begin{array}{l}\text { Dependente / Influência da } \\
\text { Idade }\end{array}$ & 8 & 2 \\
\hline C2 Total & & 11 & 1 \\
\hline
\end{tabular}

As opiniões divergiram entre a aprendizagem ao longo de toda a vida (11UR) e entre determinados momentos da vida (8UR), sendo aqui influenciada pela idade.

Quando inquiridos acerca da frequência das aprendizagens, os indivíduos quase instantaneamente respondiam que "enquanto viveres vais aprendendo" (1.4.14) (9UR), reforçando a sua posição ao mencionar o carácter diário das aprendizagens "todos os dias" (2.4.24) (2UR). De referir que ambos os casais salientam o carácter permanente das aprendizagens.

Contudo, com o decorrer da entrevista, foi possível verificar que a posição inicialmente manifestada pelos entrevistados se alterava um pouco. De facto, os entrevistados, posteriormente, referiram que a aprendizagem é influenciada pela idade, como chegam a afirmar: "quando era mais nova ... certas coisas" (1.4.17). Mas também consideraram que não condicionava o processo de aprendizagem, já que "Aprende-se o mesmo. Agora não tenho 
aprendido nada. O que sei é o que já sabia” (1.5.5). Ao que não há uma tomada de posição muito clara dos indivíduos quanto a esta questão.

É curioso como os elementos masculinos (indivíduo B e indivíduo D) salientaram apenas o carácter constante das aprendizagens, enquanto que os elementos femininos (indivíduo A e indivíduo C) alertaram para a influência da idade nas mesmas.

\section{Espaços e Tempos das Aprendizagens (Onde)}

Quando inquiridos acerca do(s) espaço(s) e tempo(s) das aprendizagens, as respostas dos indivíduos distribuíram-se do seguinte modo:

\section{Quadro 7 - Espaços e tempos das aprendizagens (Onde)}

\begin{tabular}{|l|l|l|l|}
\hline \multicolumn{1}{|c|}{ Sub-categorias } & \multicolumn{1}{|c|}{ Conteúdos dos Indicadores } & \multicolumn{1}{c|}{$\begin{array}{c}\text { Unid. } \\
\text { Reg. }\end{array}$} & $\begin{array}{c}\text { Unid. } \\
\text { Enum. }\end{array}$ \\
\hline $\begin{array}{l}\text { D1 - } \\
\text { Ambientes } \\
\text { Formais }\end{array}$ & Singer de Elvas & 4 & 1 \\
\hline D1 Total & Escola & 2 & 1 \\
\hline $\begin{array}{l}\text { D2 - Ambientes } \\
\text { Não-formais }\end{array}$ & SUÃO & 6 & 2 \\
\hline D2 Total & & 8 & 2 \\
\hline $\begin{array}{l}\text { D3 - Ambientes } \\
\text { Informais }\end{array}$ & Todo o Lado & 8 & 2 \\
\hline Contexto Rural & Casa & 8 & 2 \\
\hline
\end{tabular}

Pela observação do quadro 7, distinguem-se ambientes formais (6UR), ambientes não formais (8UR) e ambientes informais de aprendizagem (11UR).

A maioria dos indivíduos refere-se à importância das aprendizagens realizadas em contextos de carácter informal, quer sejam realizadas no campo (2UR), nas suas casas (1UR) e em todo o lado: "ai não, o aprender não tem sítio" (2.7.8.) (8UR), reforçando o que havia sido manifestado, anteriormente, pelos indivíduos.

É imperativo considerar as aprendizagens ocorridas em ambientes não formais de aprendizagem, nomeadamente na Escola Comunitária de São Miguel de Machede - SUÃO, pois os indivíduos atribuem-lhe extrema importância, como se pode verificar nas palavras de um dos indivíduos da amostra: "Adoro andar à "escola" e preciso de andar à "escola"” (2.2.17) com 8UR.

Os espaços de carácter formal foram referenciados por dois indivíduos (2UE), quando estes se referem às aprendizagens realizadas em contexto escolar, na escola de $1^{\circ} \mathrm{Ciclo}$, " $n a$ escola" (1.310) (2UR) e as ocorridas "quando entrei para a Singer, para tirar o curso" (2.2.4) (4UR/1UE).

\section{As Companhias das Aprendizagens (Com Ouem)}

Um outro tópico abordado com os indivíduos prende-se com os companheiros de aprendizagens, isto é, quais os parceiros associados às suas aprendizagens.

Quadro 8 - As Companhias das Aprendizagens (Com Quem)

\begin{tabular}{|l|l|l|l|}
\hline \multicolumn{1}{|c|}{ Sub-categorias } & \multicolumn{1}{c|}{ Conteúdos dos Indicadores } & \multicolumn{1}{|c|}{$\begin{array}{c}\text { Unid. } \\
\text { Reg. }\end{array}$} & $\begin{array}{c}\text { Unid. } \\
\text { Enum. }\end{array}$ \\
\hline $\begin{array}{l}\text { E1 - } \\
\text { Individualmente }\end{array}$ & Individualmente & 10 & 2 \\
\hline
\end{tabular}




\begin{tabular}{|l|l|l|l|}
\hline E1 Total & & 10 & 2 \\
\hline $\begin{array}{l}\text { E2 } \\
\text { Família }\end{array}$ & Família & 23 & 2 \\
\hline E2 Total & & 23 & 2 \\
\hline E3 & Pessoas & 18 & 2 \\
Em grupo & Pessoas mais Velhas que sabiam & 4 & 2 \\
& Amigos & & \\
\hline E3 Total & & $\mathbf{2 3}$ & $\mathbf{2}$ \\
\hline
\end{tabular}

Como é possível observar no Quadro 8 , todos os indivíduos se referiram à realização de aprendizagens individualmente, sublinhando: "sempre sozinho" (1.10.5) (10UR/2UE).

A aprendizagem em grupo (23UR) também é considerada pelos entrevistados. Quer seja na companhia de pessoas (18UR), como referem: "com as pessoas que saibam ensinar" (2.7.17), quer seja na companhia de pessoas mais velhas (4UR), pois "havia aqueles homens, os encarregados, os que sabiam mais do que nós" (2.8.2), quer seja na presença de "aquele amigo" (2.9.18 - 1UR).

Fazendo uma análise mais fina, constata-se que ambos os elementos do primeiro casal, apenas acrescem a companhia das pessoas mais velhas nas aprendizagens que realizaram. Há, também, que salientar a importância que o segundo casal atribui às aprendizagens ocorridas no seio da família, pois enquanto que no primeiro casal as aprendizagens entre o casal são inexistentes, no segundo, estas são muito relevantes para os seus elementos. Contudo, apenas um indivíduo refere outros familiares (pai e sogro), para lá do cônjuge, nas aprendizagens que desenvolve.

\section{Recursos da Aprendizagem (Com o Quê?)}

Os entrevistados foram igualmente questionados sobre ao que recorrem para realizar as suas aprendizagens.

\begin{tabular}{|l|l|l|l|}
\multicolumn{4}{|c|}{ Quadro 9- Recursos da Aprendizagem (Com o Quê) } \\
\hline \multicolumn{1}{|c|}{ Sub-categorias } & Conteúdos dos Indicadores & $\begin{array}{c}\text { Unid. } \\
\text { Reg. }\end{array}$ & $\begin{array}{c}\text { Unid. } \\
\text { Enum. }\end{array}$ \\
\hline $\begin{array}{l}\text { F1 } \\
\text { Pessoas }\end{array}$ & Pessoas & 5 & 2 \\
\hline F1 Total & & 5 & 2 \\
\hline $\begin{array}{l}\text { F2 } \\
\text { Meios de } \\
\text { Comunicação }\end{array}$ & Televisão & 3 & 2 \\
\hline F2 Total & & 3 & 2 \\
\hline $\begin{array}{l}\text { F3 } \\
\text { Livros }\end{array}$ & Livros & 5 & 2 \\
\hline F3 Total & & 5 & 2 \\
\hline $\begin{array}{l}\text { F4 } \\
\text { Financeiros }\end{array}$ & Dinheiro & 1 & 1 \\
\hline F4 Total & & 1 & 1 \\
\hline
\end{tabular}

De acordo com os entrevistados, quando estes realizam as suas aprendizagens, recorrem a quatro "fontes" distintas: pessoas (5UR/2UE), meios de comunicação, nomeadamente a televisão (3UR/2UE), livros (5UR/2UE) e recursos financeiros (1UR/1UE).

Analisando mais ao pormenor, verifica-se que todos os indivíduos, pertencentes aos dois casais da amostra, salientam, como recurso das aprendizagens, as pessoas (em muito por causa das companhias para as aprendizagens referenciada anteriormente: pessoas mais velhas). Como sublinham: "uns sabem uma coisa, outros sabem outra... e a gente vai aproveitando" (1.5.13).

Os meios de comunicação - televisão - são igualmente apontados como importantes recursos de aprendizagem pelos elementos femininos de ambos os casais: "a gente dá uma 
coisinha na televisão mesmo que a gente não ligue, mas há sempre uma coisinha que a gente gosta de ouvir" (2.9.11).

Uma particularidade bastante interessante é o sujeito que afirma que "com os livros aprende-se muito..." (1.6.4), considerando os livros como essenciais nas aprendizagens, pese o facto de ser analfabeto, nunca ter aprendido a ler e a escrever, nunca ter frequentado uma instituição formal, ou não formal de educação, nem ter demonstrado qualquer tipo de vontade e motivação para o fazer. Contudo, quando questionado directamente acerca da importância das aprendizagens escolares afirma que "os que sabem ler, sabem mais... com uma boa diferença. Sabem o que se passa... sabem olhar para um papel e saber o que está lá escrito" (1.3.11) ao que acresce: "porque é que as pessoas andam sempre com mapas e coisas? Sabem onde ir e não ir... agora se perguntarem a uma pessoa, ela diz vai por ali e ali... e às vezes erram... assim com os livros pouco se erra..." (1.6.7.).

Apenas um indivíduo (1UR) aponta o dinheiro como recurso de aprendizagem: "Quem não tem dinheiro não aprende nada" (1.6.8.).

\section{Estratégia das Aprendizagens (Como)}

Os entrevistados foram ainda questionados acerca do tipo de estratégia que empregam na concretização do seu processo de aprendizagem. As respostas são explanadas no quadro seguinte.

\begin{tabular}{|l|l|l|l|}
\hline \multicolumn{1}{|c|}{ Quadro 10 - Estratégias das aprendizagens (Como) } \\
\hline Sub-categorias & \multicolumn{1}{|c|}{ Conteúdos dos Indicadores } & $\begin{array}{c}\text { Unid. } \\
\text { Reg. }\end{array}$ & $\begin{array}{c}\text { Unid. } \\
\text { Enum. }\end{array}$ \\
\hline $\begin{array}{l}\text { G1 } \\
\text { Sozinho }\end{array}$ & Pensa e Faz & 16 & 2 \\
& Tentativa e Erro & 6 & 2 \\
\hline G1 Total & Memorização & 1 & 1 \\
\hline $\begin{array}{l}\text { G2 }- \\
\text { Com Pessoas }\end{array}$ & Aprende com quem sabe & 23 & 2 \\
\hline G2 Total & $\begin{array}{l}\text { Por repetição/ reprodução do } \\
\text { modelo }\end{array}$ & 10 & 2 \\
\hline $\begin{array}{l}\text { G3 } \\
\text { Com outras } \\
\text { Experiências }\end{array}$ & $\begin{array}{l}\text { Importância das Aprendizagens } \\
\text { Anteriores }\end{array}$ & 3 & 2 \\
\hline
\end{tabular}

Os indivíduos referiram a utilização de várias estratégias de aprendizagem, contudo há que ter em atenção que algumas poderão ser utilizadas de modo complementar.

Através do Quadro 10, pode-se verificar que os indivíduos empregam, nas suas aprendizagens, fundamentalmente três estratégias: aprender com quem sabe (23UE), pensar antes de fazer (16UE) e aprender por repetição/reprodução do modelo (10UE).

A aprendizagem junto de pessoas que já sabem é a estratégia mais utilizada pelos indivíduos entrevistados, sendo referenciada por todos os sujeitos (23UE/2UE). De facto, aquando da realização de novas aprendizagens os indivíduos reconhecem que "é muito importante uma pessoa saber para ensinar o outro a pensar." (2.9.2). Após estas pessoas "ensinarem e a gente aprender" (2.9.3), os indivíduos concretizam as aprendizagens "mas fazer cá à minha ideia" (2.7.16), ou seja, é necessário a existência de alguém que exemplifique e/ou demonstre para que depois o indivíduo, possa gerir e desenvolver o processo de aprendizagem "com a minha ideia" (2.7.13). Deste modo, os indivíduos confessam, inclusivamente, que "já antes de fazer uma coisa qualquer penso: há duas ou três maneiras de fazer isto... para ali é melhor" (2.10.8). 
Uma outra estratégia muito referenciada pelos indivíduos é a necessidade de existência de um "modelo" para que, posteriormente, possam reproduzir: "escrever uma coisa, a gente vai copiar e vê... temos o papel e a gente compara e vê" (2.10.2)

O modelo parece desempenhar um papel determinante e fulcral nas aprendizagens destes indivíduos.

\section{Avaliação das Aprendizagens (Quanto / Até Onde)}

Após a concretização das aprendizagens, torna-se necessário avaliar os seus resultados.

Quadro 11- Avaliação das Aprendizagens (Quanto/Até Onde)
\begin{tabular}{|l|l|l|l|}
\hline \multicolumn{1}{|c|}{ Sub-categorias } & Conteúdos dos Indicadores & $\begin{array}{c}\text { Unid. } \\
\text { Reg. }\end{array}$ & $\begin{array}{c}\text { Unid. } \\
\text { Enum. }\end{array}$ \\
\hline $\begin{array}{l}\text { H1 } \\
\text { Auto-avaliação }\end{array}$ & Auto-avaliação & 7 & 2 \\
\hline H1 Total & & 7 & 2 \\
\hline $\begin{array}{l}\text { H2 } \\
\text { Hetero-Avaliação }\end{array}$ & Hetero-avaliação & 8 & 2 \\
\hline H2 Total & & $\mathbf{8}$ & $\mathbf{2}$ \\
\hline
\end{tabular}

Como se pode ver no quadro anterior, foram identificadas duas modalidades de avaliação: a auto-avaliação (7UR) e a hetero-avaliação (8UR).

Para avaliar as suas aprendizagens os indivíduos afirmam que "a gente sabe distinguir" (2.10.4) e que "às vezes quando vejo que não está bem feito, desmancho... Vejo que não tá bem feito, não tá à minha vontade, desmancho" (1.9.13). O que revela que, primeiramente, os indivíduos avaliam por eles próprios os resultados das suas aprendizagens e só quando "a gente vê logo que já faz bem" (2.10.1), procuram uma hetero-avaliação, sendo que "gosto de mostrar aos outros, sou vaidosa" (2.10.5). Assim são reconhecidos e incentivados socialmente, pois "o que se faz é para ficar bem feito, senão é para melhorar e depois mostrar ... para ficar melhor, os outros dizerem: está como a lei" (2.10.11).

Há que salientar, novamente, a importância de um modelo aquando da avaliação das aprendizagens, pois os indivíduos avaliam-se por comparação com o mesmo, pois ao "escrever uma coisa, a gente vai copiar e vê... temos o papel e a gente compara e vê" (2.10.2).

\section{Projectos de Aprendizagem}

\begin{tabular}{|l|l|l|l|}
\multicolumn{4}{|c|}{ Quadro 12 - Os Projectos de Aprendizagem } \\
\hline \multicolumn{1}{|c|}{ Sub-categorias } & \multicolumn{1}{|c|}{ Conteúdos dos Indicadores } & $\begin{array}{c}\text { Unid. } \\
\text { Reg. }\end{array}$ & $\begin{array}{c}\text { Unid. } \\
\text { Enum. }\end{array}$ \\
\hline $\begin{array}{l}\text { I1 - Gostaria de } \\
\text { Saber }\end{array}$ & Diferentes aprendizagens & 3 & 2 \\
\hline I1 Total & Ler & 2 & 1 \\
\hline $\begin{array}{l}\text { I2 }- \text { Gostaria de } \\
\text { Fazer }\end{array}$ & Desenho & 5 & 2 \\
\hline I2 Total & Serviços do Campo & 1 & 1 \\
\hline
\end{tabular}

Os indivíduos possuem um leque diversificado de projectos de aprendizagem. Com base no quadro anterior, é possível distinguir entre o que gostaria de saber (5UR) e o que gostaria de fazer (2UR).

As aprendizagens a realizar no futuro são variadas (3UR), como é demonstrado por um dos indivíduos quando afirma que "gosto sempre de aprender. Aprender mais em tudo" (2.10.15) e para o gosto e vontade por aprender a ler, conforme é explicitado: "a teima com que eu ando... a ler" (2.10.18).

Quanto ao que gostaria de fazer, um destes entrevistados refere ainda que gostaria fazer desenho: "era desenho o que eu mais gostava de aprender. É uma coisa que não sei fazer. É o 
que mais me custa...todas saberem fazer, e eu não fazer como elas" (1.11.2), enquanto que um outro evidencia os serviços do campo: "o que mais gostava ainda, já não há... que era pegar numa junta de bois... numa carreta” (1.11.3).

\section{Atitudes face à Aprendizagem (Querer e Poder)}

Quadro 13 - Atitudes Face à Aprendizagem (Querer e Poder)

\begin{tabular}{|l|l|l|l|}
\hline \multicolumn{1}{|c|}{ Sub-categorias } & Conteúdos dos Indicadores & \multicolumn{1}{c|}{$\begin{array}{c}\text { Unid. } \\
\text { Reg. }\end{array}$} & $\begin{array}{c}\text { Unid. } \\
\text { Enum. }\end{array}$ \\
\hline $\begin{array}{l}\text { J1 } \\
\text { Querer Sempre } \\
\text { Aprender }\end{array}$ & Querer sempre aprender & 1 & 1 \\
\hline J1 Total & & 1 & 1 \\
\hline $\begin{array}{l}\text { J2 }- \\
\text { Sentir-se capaz de } \\
\text { Aprender }\end{array}$ & Capacidade para aprender & 8 & 2 \\
\hline J2 Total & & 8 & 2 \\
\hline $\begin{array}{l}\text { J3 } \\
\text { Gostar de } \\
\text { aprender }\end{array}$ & Gostar de Aprender & 5 & 1 \\
\hline J3 Total & & 5 & $\mathbf{1}$ \\
\hline
\end{tabular}

Pode apurar-se que a atitude dominante dos sujeitos face à aprendizagem é o sentimento de capacidade para a realização da mesma (8UR), o que se retirar da afirmação: "Sim, fui capaz" (2.10.25).

A vontade de querer sempre aprender é referenciada por um dos entrevistados: "Gosto sempre de aprender. Aprender mais em tudo" (2.10.15), o que se encontra relacionado com o projecto de aprendizagem futuro já demonstrado anteriormente.

Examinando, mais atentamente, o gosto pela aprendizagem é expresso pelos dois elementos do mesmo casal.

\section{Aprendizagens Não Sucedidas}

Foi pedido aos entrevistados que identificassem aprendizagens não sucedidas e, se possível, as razões/causas para o insucesso. O resultado das opiniões expressas, indicam-se no Quadro 14, que se segue:

Quadro 14 - Aprendizagens Não Sucedidas

\begin{tabular}{|c|c|c|c|}
\hline Sub-categorias & Conteúdos dos Indicadores & $\begin{array}{l}\text { Unid. } \\
\text { Reg. }\end{array}$ & $\begin{array}{l}\text { Unid. } \\
\text { Enum. }\end{array}$ \\
\hline \multirow{7}{*}{$\begin{array}{c}\text { K1 } \\
\text { Aprendizagens } \\
\text { Não Sucedidas }\end{array}$} & Andar à Escola & 10 & 2 \\
\hline & Ler e Escrever & 8 & 2 \\
\hline & Servicos do Campo & 6 & 2 \\
\hline & Matemática & 4 & 2 \\
\hline & Desenho & 1 & 1 \\
\hline & Corte e Costura & 1 & 1 \\
\hline & Outras Aprendizagens & 1 & 1 \\
\hline K1 Total & & 31 & 2 \\
\hline
\end{tabular}


A maioria dos indivíduos aponta como aprendizagens não sucedidas as de carácter escolar: matemática (4UR), ler (8UR) e a impossibilidade de frequentar a escola quando se encontravam em idade escolar (10UR).

De realçar que nesta categoria ambos os elementos masculinos dos casais referem o mesmo serviço do campo (cortiça) como aprendizagem não sucedida: "tirar cortiça, nunca aprendi" (1.3.1), mas tal deveu-se a "não calhou ir para lá... não ia ocupar aquele lugar" (2.4.4.).

Um outro indivíduo demonstra a sua angústia em não ter terminado as aprendizagens no âmbito da sua aprendizagem preferida: corte e costura: "tenho pena de não ter acabado, pois sei faço calças, faço tudo, mas não tenho carta” (2.2.14).

\section{Aprendizagens Sucedidas}

As aprendizagens sucedidas também foram alvo de estudo, como se pode verificar no quadro seguinte:

\section{Quadro 15 - As Aprendizagens Sucedidas}

\begin{tabular}{|l|l|l|l|}
\hline \multicolumn{1}{|c|}{ Sub-categorias } & \multicolumn{1}{|c|}{ Conteúdos dos Indicadores } & \multicolumn{1}{|c|}{$\begin{array}{c}\text { Unid. } \\
\text { Reg. }\end{array}$} & $\begin{array}{c}\text { Unid. } \\
\text { Enum. }\end{array}$ \\
\hline & Serviços do Campo & 18 & 2 \\
$\begin{array}{l}\text { L1 } \\
\text { Aprendizagens } \\
\text { Sucedidas }\end{array}$ & $\begin{array}{l}\text { Diferentes aprendizagens } \\
\text { escolares }\end{array}$ & 3 & 1 \\
& Matemática & 3 & 1 \\
& Outras Aprendizagens & 3 & 1 \\
\hline L1 Total & Cozinha & 2 & 1 \\
\hline
\end{tabular}

As aprendizagens sucedidas vêm, normalmente, associadas à actividade profissional e meio de subsistência dos indivíduos. Um dos indivíduos afirma que o sucesso de todas as aprendizagens que realizou: "aprendi todos os trabalhos, todos, todos" (2.4.2).

De realçar, as aprendizagens consideradas como bem sucedidas no âmbito do corte e costura (5UR), pois era "a coisa que eu mais adorei aprender, foi tricotar numa máquina de tricotar" (2.1.11).

\section{Grau de Dificuldade das Aprendizagens Quotidianas}

Os indivíduos foram ainda interrogados acerca do grau de complexidade que procuram e preferem nas suas aprendizagens.

Quadro 16 - Grau de Dificuldade das Aprendizagens Quotidianas
\begin{tabular}{|l|l|l|l|}
\hline \multicolumn{1}{|c|}{ Sub-categorias } & Conteúdos dos Indicadores & $\begin{array}{c}\text { Unid. } \\
\text { Reg. }\end{array}$ & $\begin{array}{c}\text { Unid. } \\
\text { Enum. }\end{array}$ \\
\hline $\begin{array}{l}\text { M1 - } \\
\text { Grau de } \\
\text { Dificuldade das } \\
\text { Aprendizagens } \\
\text { Quotidianas }\end{array}$ & Difícil & 4 & 2 \\
\hline M1 Total & Médio & 1 & 1 \\
\hline
\end{tabular}

Analisando o quadro anterior, constatamos que a maioria dos indivíduos prefere aprendizagens difíceis (4UR), já que "quanto mais dificeis forem as coisas, mais gosto há em aprender" (2.10.13).

Apenas existe um elemento que discorda e prefere as aprendizagens "mais ou menos" (1.12.11), isto é, aprendizagens com grau de dificuldade médio. 


\section{Oportunidades de Aprendizagem na Freguesia de Residência}

Finalmente, os indivíduos foram interrogados acerca do conhecimento que possuíam de oportunidades de aprendizagem existentes na sua freguesia de residência.

\section{Quadro 17 - As Oportunidades de Aprendizagem na Freguesia de Residência}

\begin{tabular}{|l|l|l|l|}
\hline \multicolumn{1}{|c|}{ Sub-categorias } & \multicolumn{1}{|c|}{ Conteúdos dos Indicadores } & \multicolumn{1}{|c|}{$\begin{array}{c}\text { Unid. } \\
\text { Reg. }\end{array}$} & $\begin{array}{c}\text { Unid. } \\
\text { Enum. }\end{array}$ \\
\hline $\begin{array}{l}\text { N1 - } \\
\text { As Oportunidades } \\
\text { de Aprendizagem } \\
\text { na Freguesia de } \\
\text { Residência }\end{array}$ & Nenhumas & 6 & 2 \\
\hline N1 Total & Ambiente Não Formal & 4 & 2 \\
\hline
\end{tabular}

Os entrevistados apresentaram uma posição um pouco ambígua nesta categoria, pois, por um lado, afirmaram que "não em São Miguel não há lugar" (2.10.30), o que reflecte a inexistência de oportunidades de aprendizagem na sua freguesia de residência (6UR). Por outro lado, salientam um ambiente não formal de educação, a Escola Comunitária - SUÃO (Associação para o Desenvolvimento Comunitário de São Miguel de Machede). Tal fica a dever-se, ao facto de quase todos os indivíduos frequentarem o Curso de Educação de Adultos aí ministrado.

Todavia, ainda é chamada a atenção para uma instituição formal de educação existente na freguesia: a Escola do $1^{\circ}$ Ciclo do Ensino Básico. De salientar que o indivíduo que identificou este ambiente de aprendizagem formal, é o único individuo da amostra que não sabe ler, nem escrever, que nunca frequentou uma instituição educativa ou demonstra qualquer vontade e motivação para o fazer, mas que atribui uma grande importância às aprendizagens escolares, reconhecendo que "Os que sabem ler, sabem mais... com uma boa diferença. Sabem o que se passa... sabem olhar para um papel e saber o que está lá escrito” (1.13.11).

\section{4- O Estudo das Aprendizagens no Seio da Família}

Com o objectivo de ficar a conhecer melhor as aprendizagens ocorridas em seio familiar, examinou-se ao pormenor a informação que os sujeitos proporcionaram.

\section{Aprendizagens}

Foi analisado se os indivíduos reconheciam (ou não) a existência de aprendizagens que ocorressem no seio familiar.

Quadro 18 - Aprendizagens

\begin{tabular}{|l|l|l|l|}
\hline \multicolumn{1}{|c|}{ Sub-categorias } & Conteúdos dos Indicadores & \multicolumn{1}{|c|}{$\begin{array}{c}\text { Unid. } \\
\text { Reg. }\end{array}$} & $\begin{array}{c}\text { Unid. } \\
\text { Enum. }\end{array}$ \\
\hline $\begin{array}{l}\text { A1 - Existência de } \\
\text { Aprendizagens }\end{array}$ & & 38 & 2 \\
\hline A1 Total & & 38 & 2 \\
\hline $\begin{array}{l}\text { A2 - } \\
\text { Inexistência de } \\
\text { Aprendizagens }\end{array}$ & & 12 & 1 \\
\hline A2Total & & 12 & 1 \\
\hline
\end{tabular}

Através do quadro acima, verifica-se que é reconhecida a existência de uma série de aprendizagens que têm lugar no seio familiar (38UR), contudo há que referir que um dos casais da amostra, não identificou (à partida) a existência de qualquer aprendizagem (12UR).

\section{Aprendizagens Realizadas (O Ouê?)}


Pressupondo a existência de aprendizagens em seio familiar, era então necessário proceder à sua identificação.

\begin{tabular}{|c|l|l|l|}
\multicolumn{2}{|c}{ Quadro 19- Aprendizagens Realizadas (O Quê?) } \\
\hline $\begin{array}{c}\text { Bub-categorias } \\
\begin{array}{c}\text { B1 } \\
\text { Rendizagens }\end{array}\end{array}$ & \multicolumn{1}{|c|}{ Conteúdos dos Indicadores } & $\begin{array}{c}\text { Unid. } \\
\text { Reg. }\end{array}$ & $\begin{array}{c}\text { Unid. } \\
\text { Enum. }\end{array}$ \\
\hline & Trabalhos em Contexto Rural & 14 & 2 \\
& Alfabeto - Assinar o Nome & 1 & 2 \\
& Matemática & 4 & 1 \\
\hline B1 Total & Diferentes Aprendizagens & 2 & 1 \\
\hline
\end{tabular}

Podemos observar no quadro anterior que a maioria das aprendizagens ocorridas em seio familiar são as que se relacionam com a actividade profissional do casal (trabalho em contexto rural, nomeadamente pastoreiro e transmissão dessas aprendizagens e conhecimentos, aos demais membros da família), seguindo-se as aprendizagens relacionadas com a lida da casa (6UR), pois é norma/quase obrigação, principalmente em meio rural, as mães ensinarem as filhas a "tratar da casa, tal e qual como eu" (1.7.6.).

Referência feita ainda, com algum destaque (4UR), às aprendizagens relacionadas com a matemática, o que se pode atestar quando um dos sujeitos diz que "ele sabia os números e eu não sabia” (2.2.2).

\section{Frequência das Aprendizagens (Quando)} seio familiar.

Pretendeu-se, então, caracterizar a frequência com que ocorrem estas aprendizagens no

\begin{tabular}{|l|l|l|l|}
\hline \multicolumn{1}{|c|}{ Quadro 20 - Frequência da Aprendizagens (Quando) } \\
\hline $\begin{array}{l}\text { C1 - } \\
\text { Diária }\end{array}$ & Conteúdos dos Indicadores & $\begin{array}{c}\text { Unid. } \\
\text { Reg. }\end{array}$ & $\begin{array}{c}\text { Unid. } \\
\text { Enum. }\end{array}$ \\
\hline C1 Total & Diariamente & 1 & 1 \\
\hline $\begin{array}{l}\text { C2 - Em } \\
\text { determinados } \\
\begin{array}{l}\text { Momentos da } \\
\text { Vida }\end{array}\end{array}$ & Férias Escolares & 1 & 1 \\
\hline C2 Total & & 3 & 1 \\
\hline
\end{tabular}

Como é explicitado no Quadro 20, a aprendizagem em determinados momentos vitais é dominante (4UR), sendo mais expressiva quando os menores saíam da escola (3UR) e "só depois é que passaram para o pai" (1.8.4) e iam para o campo "para as ovelhas... ajudar" (1.8.5.), garantindo assim a subsistência (financeira) familiar.

De realçar que um dos casais da amostra assegura que a aprendizagem ocorre diariamente (1UR), como se constata na citação proferida por um dos seus elementos: "Porque todos os dias o estou a ensinar" (2.5.6).

\section{Duração das Aprendizagens}

Após se apurar da frequência das aprendizagens, torna-se necessário analisar a duração dessas aprendizagens. Tal é exposto no quadro seguinte. 


\begin{tabular}{|c|c|c|c|}
\hline \multicolumn{4}{|c|}{ Quadro 21 - Duração das Aprendizagens } \\
\hline Sub-categorias & Conteúdos dos Indicadores & $\begin{array}{l}\text { Unid. } \\
\text { Reg. }\end{array}$ & $\begin{array}{l}\text { Unid. } \\
\text { Enum. }\end{array}$ \\
\hline D1 - & Curto Espaço de Tempo & 16 & 2 \\
\hline $\begin{array}{l}\text { Duraçáo das } \\
\text { Aprendizagens }\end{array}$ & & 3 & 1 \\
\hline D1 Total & & 19 & 2 \\
\hline
\end{tabular}

Verifica-se que a quase totalidade das aprendizagens ocorrem num curto período (16UR), pois as aprendizagens em meio familiar são como uma transição / "passagem" para outras actividades, como é referido: "até que arranjaram outro lado... arranjaram outros trabalhos" (1.13.10).

De notar que o carácter permanente das aprendizagens familiares é assinalado pelo elemento do casal que anteriormente refere que essas mesmas aprendizagens têm uma frequência diária.

\section{As Companhias das Aprendizagens (Com Quem)} familiares.

De seguida, tentou apurar-se quais os parceiros privilegiados nas aprendizagens

\begin{tabular}{|l|l|l|l|}
\hline \multicolumn{1}{|c|}{ Quadro 22 - As Companhias das Aprendizagens (Com Quem) } \\
\hline Sub-categorias & \multicolumn{1}{|c|}{ Conteúdos dos Indicadores } & $\begin{array}{c}\text { Unid. } \\
\text { Reg. }\end{array}$ & $\begin{array}{c}\text { Unid. } \\
\text { Enum. }\end{array}$ \\
\hline \multirow{2}{*}{ E1 - Família } & Entre o Casal & 17 & 1 \\
& Pai para Filhos & 15 & 2 \\
& Outros Familiares & 3 & 1 \\
& Sogro & 2 & 1 \\
\hline E1Total & & $\mathbf{3 7}$ & $\mathbf{2}$ \\
\hline
\end{tabular}

Relativamente às companhias nos percursos de aprendizagem, observamos que as aprendizagens que ocorrem entre o casal são as mais referenciadas (17UR), seguindo-se as aprendizagens de pais para filhos (15UR).

Torna-se, contudo, deveras importante fazer uma ressalva nesta questão, pois todas as referências das aprendizagens familiares entre o casal são feitas pelos membros desse mesmo casal, afirmando que a maioria das aprendizagens é feita justamente "eu mais a minha mulher" (2.9.17). Enquanto que os elementos do outro casal, pertencente à amostra, não reconhece qualquer aprendizagem entre os seus elementos. Tal facto é justificado por "Então, ele já sabia os serviços do campo, eu sabia os serviços do campo... ele andava sempre a guardar gado e eu nos serviços do campo" (1.8.9.).

Uma outra particularidade nesta temática, é facto de o casal, que não identifica aprendizagens no seu seio, identificar aprendizagens realizadas com os seus descendentes directos - filhos. O outro casal apenas referencia as aprendizagens que efectuou com os seus próprios pais (ascendentes), não considerando outras aprendizagens que, eventualmente, possam ter ocorrido com os seus descendentes.

Uma outra constatação verificada através de uma análise mais fina é que, no primeiro casal, ambos os sujeitos afirmam que a sua família não interferiu na sua aprendizagem e que não aprenderam com os seus pais, enquanto que, no segundo casal, um dos elementos salienta o papel (deveras importante) dos seus ascendentes directos.

Acresce ainda o facto de no primeiro casal, os sujeitos reconhecerem que um dos seus netos efectuou uma tentativa, não sucedida, de aprendizagem a um dos elementos, e, que mais uma vez, não é especificada nenhum tipo semelhante de aprendizagem no segundo casal. 


\section{Estratégias das Aprendizagens}

Quando se examinam as estratégias empregues pelos indivíduos nas aprendizagens familiares, ressalvam dois tipos: Aprende com quem já sabe (22UR) e por repetição / reprodução do modelo (2UR).

\begin{tabular}{|c|c|c|c|}
\hline \multicolumn{4}{|c|}{ Quadro 23 - Estratégias das Aprendizagens (Como) } \\
\hline Sub-categorias & Conteúdos dos Indicadores & $\begin{array}{l}\text { Unid. } \\
\text { Reg. }\end{array}$ & $\begin{array}{l}\text { Unid. } \\
\text { Enum. }\end{array}$ \\
\hline F1- & Aprende com quem sabe & 22 & 2 \\
\hline & $\begin{array}{l}\text { Por repetição/ reprodução do } \\
\text { modelo }\end{array}$ & 2 & 1 \\
\hline F1Total & & 24 & 2 \\
\hline
\end{tabular}

Como se pode verificar através do quadro acima, a existência de uma pessoa que já tenha conhecimentos acerca das aprendizagens a realizar é fundamental. Novamente, é salientada a importância de um modelo que os sujeitos possam reproduzir.

\subsection{Leitura da Informação Recolhida...}

A partir dos dados recolhidos, através das entrevistas que foram realizadas e cujo conteúdo foi anteriormente apresentado, é possível evidenciar algumas regularidades nas estratégias de aprendizagem:

i. Em primeiro lugar, quando se verifica a existência de aprendizagens no seio da família, parece existir um eventual papel liderante da mulher na concretização das mesmas.

De facto, são os elementos femininos que conduzem as aprendizagens, sendo as suas promotoras. Relativamente ao Casal 1, as aprendizagens que se concretizaram com os seus descendentes foram, na sua maioria, da responsabilidade da mulher; verificando-se o mesmo no Casal 2, pois quem orienta e transmite, ao cônjuge, as indicações necessárias à realização das tarefas/aprendizagens é o elemento feminino.

ii. Em segundo lugar, verifica-se a existência de uma "rede" de aprendizagens no seio da Família. Existe, como que uma "transferência" de aprendizagens anteriormente adquiridas, isto é, os conhecimentos e as práticas da família não ficam "reféns" dos seus possuidores, sendo transmitidas aos restantes elementos.

iii. Podemos igualmente referenciar a existência de um modelo aquando do desenvolvimento das aprendizagens. Os entrevistados necessitam de uma "referência", alguém, ou algo que, possa ser a base da sua aprendizagem e que tenha a capacidade de "detonar" o pensamento e procedimento dos sujeitos, para que, posteriormente, já possam gerir e desenvolver as aprendizagens autonomamente.

iv. Há que realçar, ainda, uma outra regularidade encontrada: o carácter individual das aprendizagens, isto é, um eventual traço dos estilos de aprendizagem solitário. De facto, os entrevistados confessam a sua preferência por trabalharem sozinhos, pese embora o facto de existir, muitas vezes, um primeiro contacto com outros. No entanto, são os próprios que identificam as estratégias que melhor lhe servem para determinada aprendizagem. Contudo, 
uma vez terminado o processo de aprendizagem, o indivíduo tende a procurar o contacto relacional, numa tentativa de ver o seu trabalho valorizado e reconhecido socialmente.

\section{Referências Bibliográficas}

Benavente, A. (1996) (Coord.). A Literacia em Portugal. Resultados de uma Pesquisa Extensiva e Monográfica. Lisboa: Fundação Calouste Gulbenkian.

Canário, R. (2000). Educação de Adultos. Um Campo e Uma Problemática. Lisboa: Educa.

Castro-Caldas, A. (1993). "Problems os testing aphasia in illiterate subjects" in F. Stachowiak et al (Edits). Developments in the Assessment and Rehabilitation of Brain-Damaged Patients. Luxembourg: Gunter Narr Verlag Tübingen.

Castro-Caldas, A. (2002). O Cérebro Analfabeto. A influência do conhecimento das regras da leitura e da escrita na função cerebral. Lisboa: Bial.

Castro-Caldas, A. (2003). "Como encontrar áreas de interesse para estudar o cérebro analfabeto", Revista Psychologica, 34.

Castro-Caldas, A. \& Reis, A. (1998). "O analfabetismo no contexto dos modelos de estudo em Neuropsicologia”. Neuropsych Latina, 4 (2).

Castro-Caldas, A. et al (1998a). The illiterate brain. Brain, 121., pp.1053-1063.

Castro-Caldas, A. \& Reis, A. (2000). "Neurobiological substrates of illiteracy". The neuroscientist, Vol.6, p.6.

Cavaco, C. (2002). Aprender fora da Escola - Percursos de Formação Experiencial. Lisboa: Educa.

Covas, M. (2006). Percursos da Sociologia da Família: das origens à consolidação científica. Faro: Universidade do Algarve.

Duarte, A. et al (2004). "O Que Importa a Idade: Projecto Educativo Desenvolvido na Santa Casa da Misericórdia de Vimieiro" - in José Nico et al (Orgs) Aprender no Alentejo. Actas do II Encontro Regional de Educação. Évora: Departamento de Pedagogia e de Educação da Universidade de Évora, p.191.

D’Espiney, R. (2004). "Comentário Síntese das Três Experiências" - in José Nico et al (Orgs) Aprender no Alentejo. Actas do II Encontro Regional de Educação. Évora: Departamento de Pedagogia e de Educação da Universidade de Évora, p.81.

Instituto Nacional de Estatística (2003). Antecedentes, Metodologia e Conceitos: Censos 2001: XIV Recenseamento Geral da População; IV Recenseamento Geral da Habitação / Instituto Nacional de Estatística. - Lisboa: INE.

Mata, L. (2006). Literacia Familiar. Ambiente familiar e descoberta da linguagem escrita. Colecção Infância. Porto: Porto Editora.

Neira, T. (2003). "Pedagogia y educación familiar". in Gervilla, Enrique (Coord). Educación Familiar. Nuevas relaciones humanas e humanizadoras. Madrid: Narcea, pp.13-25.

Orta, J.. (2003). Nasce do Meu Pensamento. Alandroal: Confraria do Pão.

Pereira, I. (2004). "Quinta da Educação e Ambiente - Um Projecto de Requalificação do Local - Reserva Natural das Lagoas de Santo André e da Sancha". in J. Nico et al (Orgs). Aprender no Alentejo. II Encontro Regional de Educação. Évora: Departamento de Pedagogia e de Educação da Universidade de Évora, pp.67-73.

Vara (1996). Título. Recuperado em 14 de Julho de 2006, de <http://pt.wikipedia.org/> 